\title{
Renewable Energies, Lamps and Communication Technologies: A Review
}

\author{
Karande A.A. ${ }^{1}$, Kadam M.M. ${ }^{2}$ \\ Student- Bachelor of Engineering, Department of Electronics and Telecommunication Engineering, Dr. Daulatrao Aher \\ College of Engineering, Karad, India ${ }^{1}$ \\ Assistant Professor, Department of Electronics and Telecommunication Engineering, Dr. Daulatrao Aher College of \\ Engineering, Karad India ${ }^{2}$
}

\begin{abstract}
Now a days the use of electricity is a measure issue in an India. Where the wastage of light observed highly in street lighting area. Street light system performs an important role for providing security at night times, for avoiding accidents during night time and also for avoiding many other problems. The street light can be controlled manually but this method is very costly and difficult to monitor, it involves high power consumption and this system is time consuming. So to avoid this problem we can automatically monitor street lighting system by using GSM. The problem of power consumption can be minimized by using renewable energy source instead of using conventional source. Renewable energy causes energy saving and system is ecofriendly. By using renewable energy sources many problems can be solved. In this paper we make a review on renewable sources, lampposts and communication technologies.
\end{abstract}

Keywords: Renewable energy source, street lights, communication technology.

\section{INTRODUCTION}

In previous systems numbers of street lamps are less but power consumption. Finally this project achieved 28-32\% with development of urbanization the numbers of streets power consumption with just a 3-5\% illumination increase rapidly. There are some factors needs to be reduction. In paper [2] they use zigbee based wireless considered during designing of good street lighting technology which allow more efficient street lighting system. When considering the effects of technical system system. It uses many sensors for controlling the system. on the environment energy is the most important Zigbee is used to transfer information in point-by-point parameter. The traditional street light system is not much manner. This system is mainly appropriate for street effective system it includes disadvantages like high power lighting in remote urban and rural areas where the traffic consumption, high cost and more manual work.

low.

The above problems can be minimized by using various Paper [3] introduces new technologies which offers easy methodologies as:

- Use renewable energy source instead of using conventional power sources.

- Use LED lighting technology which gives energy efficiency, ecofriendly environment.

- Remote control system- In this LED lamp will be ON/OFF manually.

Lighting control is one of the important parameter in intelligent buildings. The invention of LED lighting device consumes half of energy than fluorescent lighting device. Solar powered street lighting system is proposed in order to reduce burning of fossil fuels, to generate electricity, to reduce air pollution. For this purpose we introduce renewable energy source based street lighting system.

\section{LITURATURE REVIEW}

The paper [1] is based on remote control. They use master and slave boards. Master board is placed in electrical panels and slave board is place on each lamppost which are used to turn ON/OFF the lamppost which causes maintenance and energy saving. Here in this paper they used conventional source. The [4] paper is based on zigbee technology which effective management. Here 20-22\% power reduction is possible. GSM based Automatic Street light control system which depends on light intensity and traffic density introduced in paper [5].This project is cost effective and the general purpose of project is reduction of crime.Paper [6] is completely based on different sensors, lamps and different publications. It satisfies the problems faced by common street lighting system. This paper deals with survey on experimental part of research.The comparison of zigbee with other technologies is given in paper [7]. This system can be elongate, modifiable and adaptive new technologies.

The paper [8] is a review on comparative study on various wireless technologies which are used to build different smart networks. The contents of paper [9] are policies of India about renewable energy sources. There are various renewable energy sources introduced in this paper such as hydroelectricity, geothermal, biomass, solar, wind. 
International Advanced Research Journal in Science, Engineering and Technology

National Conference on Emerging trends in Electronics \& Telecommunication Engineering (NCETETE 2017)

AGTI's Dr. Daulatrao Aher College Engineering, Vidyanagar Extension, Karad

Vol. 4, Special Issue 2, January 2017

III.

COMPARATIVE STUDY OF LAMPS

street lighting etc. Following tables gives information about different lamps and describes how they are different

There are different types of lamps. Lamps are necessary from each other.

for lighting in home, society, buildings, hospitals, for

Table 1. Comparison of various lamps:

\begin{tabular}{|l|l|l|l|l|}
\hline Sr. No. & Lamp & Days & Efficacy(lumens/watt) & Characteristics \\
\hline 1. & Incandescent & $42-208$ & $11-15$ & Extremely ineffective \& short life time \\
\hline 2. & $\begin{array}{l}\text { Mercury } \\
\text { Vapour }\end{array}$ & $500-1000$ & $13-48$ & $\begin{array}{l}\text { Very ineffective, UV emission\& contains } \\
\text { mercury }\end{array}$ \\
\hline 3. & Metal Halide & $417-625$ & $60-100$ & $\begin{array}{l}\text { High maintenance, UV emission contains } \\
\text { mercury and lead, danger of blasting at end } \\
\text { of life }\end{array}$ \\
\hline 4. & $\begin{array}{l}\text { High pressure } \\
\text { Sodium }\end{array}$ & $500-1000$ & $45-130$ & \begin{tabular}{l} 
Contain mercury \& lead \\
\hline 5.
\end{tabular} \\
$\begin{array}{l}\text { Low Pressure } \\
\text { Sodium }\end{array}$ & $417-750$ & $80-180$ & Contain mercury \& lead \\
\hline 6. & Fluorescent & $417-833$ & $60-100$ & $\begin{array}{l}\text { UV emission and contains mercury \& } \\
\text { diffused non-directional light }\end{array}$ \\
\hline 7. & $\begin{array}{l}\text { Compact } \\
\text { Florescent }\end{array}$ & $500-833$ & $50-72$ & $\begin{array}{l}\text { Short life, dimmer in cold weather \& } \\
\text { contains mercury }\end{array}$ \\
\hline 8. & Induction & $2500-4167$ & $70-90$ & High initial cost, limited directionality \\
\hline 9. & LED & $2083-4167$ & $70-150$ & High initial cost \\
\hline
\end{tabular}

\section{COMPARATIVE STUDY OF RENEWABLE ENERGY SOURCES}

renewable energy sources. Renewable energy is the energy which is regenerated by using natural sources such as water, sun, wind, etc. Hydroelectricity, geothermal,

Energy is mainstay of technology and economic biomass, solar and wind energy are the various types of development. India can fulfill all energy needs with renewable energy sources.

Table 2. Comparison of different renewable energies:

\begin{tabular}{|c|c|c|c|c|c|c|}
\hline Sr. No & Parameter & Hydropower & Geothermal & Biomass & Solar & Wind \\
\hline 1. & $\begin{array}{l}\text { Installation } \\
\text { cost }\end{array}$ & High & High & Low & Moderate & Moderate \\
\hline 2. & Location & $\begin{array}{l}\text { Not suitable in } \\
\text { many location } \\
\text { due to lack of } \\
\text { resources }\end{array}$ & $\begin{array}{l}\text { Suitable to } \\
\text { particular } \\
\text { regions }\end{array}$ & $\begin{array}{l}\text { Rural/village } \\
\text { areas }\end{array}$ & $\begin{array}{l}\text { Installed on } \\
\text { rooftops }\end{array}$ & $\begin{array}{l}\text { Installed in } \\
\text { open and } \\
\text { spacious area }\end{array}$ \\
\hline 3. & Source & Water & $\begin{array}{l}\text { Underground } \\
\text { heat }\end{array}$ & $\begin{array}{l}\text { Cow dung, } \\
\text { Organic } \\
\text { components }\end{array}$ & Sun & Wind \\
\hline 4. & $\begin{array}{l}\text { Impact on } \\
\text { ecosystem }\end{array}$ & More & More & Less & Less & Less \\
\hline 5. & Problems & $\begin{array}{l}\text { In colder climate } \\
\text { freezing of pipes }\end{array}$ & $\begin{array}{l}\text { May release } \\
\text { harmful gases }\end{array}$ & $\begin{array}{l}\text { May release } \\
\text { harmful gases }\end{array}$ & $\begin{array}{l}\text { Absence of } \\
\text { sunlight }\end{array}$ & $\begin{array}{l}\text { Direction and } \\
\text { pressure of air }\end{array}$ \\
\hline 6. & Pollution & No & Yes & Yes & No & No \\
\hline 7. & Maintenance & High & High & High & Low & Low \\
\hline
\end{tabular}

\section{COMMUNICATIONTECHNOLOGIES}

There are different types of communication technologies used for wireless communication such as Bluetooth, WiFi, Zigbee, GSM etc.
Table 3. Comparison of various communication technologies:

\begin{tabular}{|l|l|l|l|l|}
\hline Parameter & Bluetooth & Wi-Fi & Zigbee & GSM \\
\hline Range & $10 \mathrm{~m}$ & $100 \mathrm{~m}$ & $100 \mathrm{~m}$ & $0.5 \mathrm{k}$ \\
\hline
\end{tabular}


IARJSET

International Advanced Research Journal in Science, Engineering and Technology

National Conference on Emerging trends in Electronics \& Telecommunication Engineering (NCETETE 2017)

AGTI's Dr. Daulatrao Aher College Engineering, Vidyanagar Extension, Karad

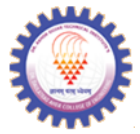

Vol. 4, Special Issue 2, January 2017

\begin{tabular}{|c|c|c|c|c|}
\hline & & & & $\begin{array}{l}\mathrm{m} \text { to } \\
35 \mathrm{~km}\end{array}$ \\
\hline Data rate & $1 \mathrm{Mbps}$ & $\begin{array}{l}11-50 \\
\text { Mbps }\end{array}$ & $\begin{array}{l}2040250 \\
\text { kbps }\end{array}$ & $\begin{array}{l}270 \\
\text { kbps }\end{array}$ \\
\hline Frequency & $2.4 \mathrm{GHz}$ & $\begin{array}{l}2.4 \text { to } \\
5 \mathrm{GHz}\end{array}$ & $2.4 \mathrm{GHz}$ & $\begin{array}{l}900 \mathrm{M} \\
\mathrm{Hz} \\
\text { band }\end{array}$ \\
\hline $\begin{array}{l}\text { Power } \\
\text { consumption }\end{array}$ & medium & high & Verylow & low \\
\hline Complexity & High & high & low & low \\
\hline Battery life & 1 to 7 days & $\begin{array}{l}1 \text { to } \\
5 \text { days }\end{array}$ & $\begin{array}{l}100 \text { to } \\
1000 \text { days }\end{array}$ & $\begin{array}{l}\text { More } \\
\text { than } \\
\text { zigbe } \\
\mathrm{e}\end{array}$ \\
\hline Cost & Low & $\begin{array}{l}\text { Medi } \\
\text { um }\end{array}$ & Low & High \\
\hline $\begin{array}{l}\text { IEEE } \\
\text { standard }\end{array}$ & 802.15 .01 & $\begin{array}{l}802.1 \\
\text { 1bgn } \\
\end{array}$ & $\begin{array}{l}802.15 .0 \\
4\end{array}$ & $2 \mathrm{G}$ \\
\hline
\end{tabular}

[8] AmolBaviskar, JaypalBaviskar, AfshanMulla, Nilesh Jai and Ajay Radke, Comparative Study of Various Wireless Technology for Smart Grid Communication: A Review in International Journal on Recent and Innovation Trends in Computing and Communication ISSN: 2321-8169Volume: 4 Issue: $4874-881$.

[9] RuchaKorhale,Paper Presented on Renewable Energy Sources Policies of India.

The continuous increase in use of nonrenewable energies has created problems of demand and supply. Because of this the future of non renewable energies becoming uncertain. Energy is mainstay of technology and economic development. Energy problem is global problem. It is not possible for government to do everything to solve this problem. So we have to try individually with co-operative manner.

We introduce solar and wind energy together in our project. To reduce power consumption we will use LED lamp. Out of various communication technologies we select GSM technology because it has long range as compared to other.

\section{REFERENCES}

[1] R. Caponetto, G. Dongola, L. Fortuna, N. Riscica and D. Zufacchi, Power Consumption Reduction in a Remote Controlled Street Lighting System in SPEEDAM 2008International Symposium on Power Electronics, Electrical Drives, Automation and Motion.

[2] Fabio Leccese, ZbigniewLeonowicz, Intelligent wireless street lighting system.

[3] Prof. K.Y.Rajput, GargeyeeKhatav, Monica Pujari, PriyankaYadav, Intelligent Street Lighting System Using GsmInternational Journal of Engineering Science Invention Volume 2 Issue 3 | March. 2013.

[4] R. Santhosh Kumar, Dr. Prabu, S. Vijaya Rani and P.Venkatesh Design and Implementation of an Automatic Solar Panel BasedLed Street Lighting System Using Zigbee and Sensors in Middle-East Journal of Scientific Research 23 (4): 573-579, 2015(C) IDOSI Publications, 2015.

[5] Shilpashree R N, Shruthi H O, Smitha S, Veenashree C N, Arpitha Shankar S I, Gsm Based Automation Of Street Light in IJISET International Journal of Innovative Science, Engineering \& Technology, Vol. 1 Issue 3, May 2014.

[6] R. Santhosh Kumar, M. Prabu , P. Venkatesh and S. Vijaya Rani, An Automatic Solar Panel Based StreetLighting System: A Systematic LiteratureReview in I J C T A, 8(2), 2015, pp. 531-542.

[7] Mr. Dipak A. Mhaske Prof. S. S. Katariya, Smart Street Lighting using a ZigBee\& GSMNetwork for High Efficiency \& Reliability in International Journal of Engineering Research \& Technology (IJERT)ISSN: 2278-0181 Vol. 3 Issue 4, April - 2014 